\title{
The Importance of Food Control for Retail Development - Evidence Using Adaptive Neuro-Fuzzy Inference System Approach
}

\author{
Svetlana Sokolov Mladenovic ${ }^{1}$, Sreten Cuzovic ${ }^{1}$, Igor Mladenovic ${ }^{1}$, Dragan Stojkovic ${ }^{2}$ \\ ${ }^{1}$ Faculty of Economics, University of Nis \\ Square King Alexander 11, 18000 Nis, Serbia \\ E-mail.svetlana.sokolov@eknfak.ni.ac.rs; sreten.cuzovic@eknfak.ni.ac.rs;igor.mladenovic@eknfak.ni.ac.rs
}

${ }^{2}$ Faculty of Economics, University of Belgrade

Kamenicka 6, 11000 Belgrade, Serbia

E-mail.dstojkovic@ekof.bg.ac.rs

cross $^{\text {ref }}$ http://dx.doi.org/10.5755/j01.ee.31.5.24484

\begin{abstract}
Retail and retail development have become increasingly important in the economies of a number of countries in recent years. Given that retail chains are in direct contact with consumers, food retail control is important for both consumers and retailers. Additionally, food control is an important business segment of all companies involved in the food distribution chain, from food production, processing, storage, and sales to end consumers. On the one hand, the right to healthy and safe products is one of the basic consumer rights. On the other hand, retail chains tend to deliver healthy and safe products to consumers, using the principle of efficiency and positive business performance. In line with the above, i.e. food retailers' challenge to satisfy consumer demands for healthy and safe products, but also to achieve positive business performance, the aim of this paper is to analyse the importance of food control for retail development, with particular reference to the market of the Republic of Serbia. For this purpose, empirical research is carried out on a sample of 169 food retailers. Using the available financial data, as well as data obtained from field research, the paper tests hypothesis on the impact of food control, as measured by the percentage allocation for the introduction of food safety standards, on food retail performance. The ANFIS method is used, and the results show positive impact of food control on food retail development in the Republic of Serbia.
\end{abstract}

Keywords: Food Control; Retail; Business Performance; Serbia; Multiple Regression Model.

\section{Introduction}

Trade, especially retail and food retail, is facing a number of challenges. Retail in the $21^{\text {st }}$ century differs considerably in comparison with retail in the past (Diamon \& Litt, 2010, p. 10). Retail, as well as food retail, as its integral part, is an important economic segment in a number of countries, and develops in accordance with production and consumption development trends. The situation in a number of economies proves this, as seen through the impact of retail on consumer lifestyle and economic prosperity (Dunne, Lusch \& Carver, 2014, p. 2). Statistical data on retail share in gross domestic product, employment, and gross added value of individual economies is another confirmation. On the other hand, retailers are in direct contact with consumers and have a "privilege" in relation to other participants in the distribution chain to be the first to obtain information from consumers about their satisfaction or dissatisfaction with products. Similarly, they have a huge responsibility to consumers to provide them with healthy and safe products, especially when it comes to food. All of these facts support the thesis that food control is a business imperative for food retail chains. Additionally, to prove this, food retail has a growing share in total retail both in terms of sales volume and as regards business formats (Global Power of Retailing, 2014-2018).

Given the increasing importance of food retail, on the one hand, and the responsibility of retailers to provide customers with healthy and safe products, on the other, the question that arises is how the introduction of food control affects retailers, i.e. their business performance. This issue is also the research subject, and the aim of the paper is to analyze the impact of food control on the business performance of retailers engaged in the sale of agri-food products. The motive for this research is that previous studies have scarcely addressed the issue of the importance of food control for retailers. The existing studies mainly deal with the introduction of food control systems into business from customer perspective (Porin \& Mainsant, 1999; Henson \& Northen, 2000; Verbeke \& Viaene, 2001). Few studies address the effects of introducing food control for companies themselves (Herath \& Henson, 2006; Sarter et al., 2010; Scott, Wilcock \& Kanetkar, 2009). These studies lack an analysis of the impact of the introduction of food control on retailers' business performance. This research will fill this gap, which also reflects its novelty in relation to earlier studies and their results.

For this purpose, the paper is divided into three segments. The first segment, based on available literature, analyzes the growing importance of retail and food retail, with the focus on the largest retail chains in the world, as well as food retail on the market of the Republic of Serbia. The second part analyzes the application of food control in Serbia, seen institutionally and legally. The third segment of the paper focuses on empirical research involving a sample of 169 food retailers in Serbia. Using publicly available 
data, as well as data obtained by interviewing these companies, the ANFIS method is applied, to test the hypothesis of the impact of investment in food quality control, measured by the percentage of allocations for the introduction of food quality standards, on business performance of food retailers. The results show positive impact of investment in quality control on the business performance of companies in the food retail segment.

\section{Literature Review \\ Development of Retail and Food Retail}

Retail, as well as food retail, as its integral segment, represents the service sector of the economy that has gained importance in recent years, taking into account the share of retail in GDP, employment, and gross value added (Eurostat, 2018). In addition, retail and changes that take place have been the main research subject at the turn of the century (Levy et al., 2014; Berman et al., 2018; Grewal, Motyka \& Levy, 2018; Brynjolfsson et al., 2013; Grewal et al., 2011; Hagberg, Sundstrom \& Egels-Zanden, 2016; Hristov \& Reynolds, 2015). All these studies show that retail has a dominant role in transport channels in early $21 \mathrm{st}$ century. Lovreta \& Petkovic (2018, p. 8) find the reason for this in the concentration of capital and information. Capital concentration strengthens economic and purchasing power of retail companies, which in negotiations with suppliers try to achieve the best possible conditions: the lowest purchase prices, more favourable payment terms, the most convenient place of delivery of ordered goods etc. On the other hand, direct contact with consumers is retailers' strategic advantage in relation to other participants along the marketing channel. Retail has the most information about consumers' needs and demands, trends in demand fluctuation, and the expected product characteristics. This role is especially important in the era of information technology and software that offer the possibility of a very fast and reliable analysis of collected information and processing of data registered on EPOS terminals. Other participants in marketing channels become dependent on this information, as it significantly affects the projection of new product development, investment and production series planning. Hence, the great negotiating power and significant information available to retailers has changed the traditional understanding of how marketing channels work. For producers themselves, the traditional thesis "customer is the king" is replaced by "retailer is the king". In modern conditions, when a large number of producers can make products of very similar characteristics, intangible benefits and properties of products and services gain in importance. Thus, trade structures an adequate "package deal", seeking to create this superior consumer value.

Based on the above, as well as retail research results (Kunc \& Krizan, 2018, Finnegan et al., 2016; Souiden, Ladhari \& Chiadmi, 2019), it is possible to highlight the key flows that mark retail, and, consequently, food retail:

- Retail assumes a dominant position and a central role in key processes that are continually taking place in marketing channels;

- Retail capital concentration leads to increased negotiating power and subsequently to creating oligopolies at retail markets;

- In order to better meet consumer needs, all forms of integration and cooperation are intensified;

- Price competition loses its significance; instead, the quality of products and services is in the foreground;

- Private brand development encourages retail companies to engage in activities traditionally performed by producers, in particular in new product development, product launch, product advertising, etc.;

- Intensive development of all forms of electronic and omnichannel commerce and application of modern technology increase the efficiency of retail companies;

- In conditions of increasingly intense competition and saturation of the domestic market, many retail companies decide to internationalize their business.

Therefore, these flows permeate all aspects of retail, including food retail, which includes all business activities related to product sale (in food retail these are agri-food products) and services to end users for personal, family, or household use.

The fact that food retail is gaining in importance is illustrated by available trade volume data of the largest retail chains in the world. Specifically, the Deloitte Touche consulting firm at the beginning of each year publishes the list of the 250 largest retail chains in the world, observed in terms of sales volume (Global Power of Retailing, 20152019). The Global Power of Retailing report for the past five years (2015-2019) allows monitoring sales trends of the largest retail chains, as well as those dealing with food retail.

Despite the decline in the share of food retail sales volume in the period from 2013 to 2017 , its percentage share remains at a significant level, and, in 2017, it was $66,2 \%$ of food retail sales volume compared to the total sales volume of 250 largest retail chains.

Regarding the market of the Republic of Serbia, the available statistical data shows the trend in the food retail sales volume (Table 1).

Table 1

Trend in Total Retail and Food Retail Sales Volume in the Republic of Serbia in Millions of RSD (2013-2017)

\begin{tabular}{|l|c|c|c|c|}
\hline \multicolumn{1}{|c|}{ Years } & $\mathbf{2 0 1 3}$ & $\mathbf{2 0 1 4}$ & $\mathbf{2 0 1 5}$ & $\mathbf{2 0 1 6}$ \\
\hline Sales volume in total retail & 1203966 & 1253924 & 1269676 & 1366044 \\
\hline Food retail sales volume & 377776 & 401266 & 413520 & 1477255 \\
\hline
\end{tabular}

Source: Statistical Yearbook of the Republic of Serbia 2014-2018.,www.stat.gov.rs/publikacije/publication/?p=10399

Table 1 shows the tendency of rise in the share of food retail in total retail in the Republic of Serbia.

Food Control in Europe and the Republic of Serbia
Food safety and control are one of the main topics in public debates on food policy and food industry, but also in research over the past 20 years (Scarpato et al., 2017, Heikkila et al., 
2016; Al-Busaidi \& Jukes, 2015; Al-Kandari \& Jukes, 2012; Alomirah et al., 2010; Kettunen et al., 2017). Additionally, the awareness of all stakeholders in food production and delivery chain of the need for food safety and security has increased, on the one hand, while increasingly intense global competition has affected the food industry to apply different methods and standards in order to increase quality in production and sales processes, which ultimately leads to consumer safety (Grunet, 2005; Meziane 2007; He, Deng \& Hwang, 2019; GarciaGarcia, Stone \& Rahimifard, 2019).

The theory and practice point to the fact that demand and supply of agri-food products have faced numerous changes in the last few years, such as a technological revolution that has increased the number and availability of food products, but also new problems with the long-term effect on human health and environment (e.g. GMO). Numerous diseases and consumer problems caused by food consumption have led to food safety and control taking a significant place in the policies of the European Union and its member states. In addition, one of the basic consumer rights is the right to safe products, including food, which is institutionalized through consumer protection policy (European Commission, 2013). These rights are additionally guaranteed by numerous directives and policies. Thus, the first European Union food hygiene rules were adopted in 1964 (European Commission, 2013). Since then, these rules have been constantly evolving to become a proactive tool for the protection of human health, as well as environment, as well as to ensure the safety of food production and trade.

The basic principles of the European Union food safety policy are defined in the General Food Law, adopted in 2002 (European Commission, 2014). The general objectives of this law relate to facilitating free food trade in all EU member states while ensuring a high level of consumer protection. Additionally, this law covers a large number of issues related to food safety and control, i.e. covers all segments of food chain, ranging from animal feed, through food production, processing, storage, transportation to retail. This points to the fact that retail is an integral segment of the food chain and that food safety and control in retail are of great importance, especially due to the fact that it has the "privilege" of direct contact with consumers, which was discussed above. Such an integral approach implies that food produced and sold in the European Union can be controlled from "farm to table" and that it gives consumers additional security in terms of food safety.

Based on the foregoing, it can be noticed that the EU food policy is based on clear scientific assessment and detailed risk assessment. In addition, EU institutions rely on scientific boards and independent agencies such as the European Food Safety Authority (EFSA). This agency's scope of work relates to risk assessment before food products can be marketed on the EU market, as well as giving various advice in order to make effective decisions for consumer protection. The key role of the agency is to respond rapidly to crises related to food safety (European Food Safety Authority, 2018).

Based on the foregoing, it can be noted that food safety and control are an exceptionally complex problem. This requires: appropriate theoretical and practical knowledge, reliable information on food production and sale, as well as the criteria behind quality control and optimal working conditions. If all this is provided, the quality of food can continually improve. Given that the Republic of Serbia is in the process of joining the European Union, it is necessary to take all measures for the introduction and implementation of food quality standards. Specifically, as of 1 January 2006, food safety standards, primarily HACCP, are mandatory on the EU (Council Directive 93/43/EEC) and the World Trade Organization markets. According to the Codex Alimentarius definition, HACCP is a system for identifying, evaluating, and controlling hazards of importance for food safety. HACCP (Hazard Analysis Critical Control Points) is a food safety system based on the analysis and control of potential biological/microbiological, chemical and physical hazards to raw material, potential hazards in the handling, production, distribution, and consumption of ended products. It is adapted to all types of food products and all types of food production and handling. Companies that do not have business certificates in accordance with these standards will not be able to place their goods on the European Union market. Legislation of almost all developed countries obliges food producers in these countries to introduce the HACCP system.

For this reason, the Republic of Serbia has accepted this safe food concept, so that as of 1 January 2009 HACCP has become binding on the Serbian market, and companies that do not have business certificates in accordance with this system will not be able to export and sell their products in the Republic of Serbia or export to other markets. This practically means that in addition to food industry (food producers), everyone has the obligation to implement the HACCP system, from those involved in product preparation, food processing, storage, to packing, transport, or sale entities. The program of mandatory implementation of the HACCP system includes: caterers, traders, animal feed producers, packaging manufacturers, institutions and organizations organizing meals, as well as transport companies.

To sum up, the Food Safety Law has established a chain of control from farm to table in order to ensure food safety, and make every consumer on the market sure that the food they consume meets all health, hygienic, and quality requirements, which is achieved by establishing the Central Registry of all entities in the production of food, as the first step in establishing the responsibility of food business operators. It is the obligation of all entities to respect the principle of risk and precautionary analysis, as well as the principle of consumer protection and transparency.

Given the above, a number of authors have begun to analyze consumer concerns and interest in food safety in recent years. In this context, they explore the potential impact of marketing strategies and the introduced food control system on consumer confidence in food safety. Thus, numerous studies analyse the extent to which consumers make the decision to purchase food based on their belief in its safety (Porin \& Mainsant, 1999; Henson \& Northen, 2000; Verbeke \& Viaene, 2001; Liu et al., 2019). As consumers cannot be sure of the food quality immediately before or after purchase, quality certification and food safety strategies are of particular importance (Caswell, 1998; Stefani \& Henson, 2001). Thus, some of these studies identify the long-term benefits of introducing food safety standards, in particular HACCP (Herath \& Henson, 2006; Sarter et al., 2010; Scott, Wilcock \& Kanetkar, 2009), such as: a) the ability to sell products at higher prices b) reducing production and sales costs, c) increasing product consistency, d) increasing consumer 
confidence, e) increasing market share, f) increasing employee commitment to improving food safety, and e) reducing market risk. On the other hand, research shows that the introduction and continuous application of HACCP in small and medium-sized enterprises indifferent sectors is a rather complex process limited by a number of factors (Violaris, Bridges \& Bridges, 2008; Yapp \& Fairman, 2006), reflected in lack of knowledge, financial resources, time necessary for the establishment and introduction of HACCP, and others. The results of these studies suggest that it is necessary to engage external experts to develop, implement, and manage the HACCP system.

A review of literature reveals that previous studies on food control mainly focus on customers and their views on the introduction of food control. Using a different methodology, these studies analyze customer confidence in companies working to introduce food control, primarily HACCP (Henson \& Northen, 2000; Verbeke \& Viaene, 2001; Scarpato et al., 2017). They highlight certification and food safety strategies, which have been shown to provide customers with additional confidence in the quality of food products. Unlike these studies, another group of studies analyze the long-term benefits of introducing HACCP for companies and their operations. They identify multiple benefits, highlighting production and sale cost reduction as economic effects. A review of literature and previous studies reveals that few studies address the impact of the introduction of food control, primarily HACCP, on the business performance of companies, especially retailers. This points to a gap in the scientific and professional literature in the field of food control and retail.

This has been the motive to define the research problem and hypotheses in this paper. In addition, food retail is gaining in importance, both internationally and in the Republic of Serbia, with retail itself being an important link in food delivery to final consumers. In addition, the introduction of food quality standards is a commitment of the Republic of Serbia as a potential member of the European Union. All this influenced the definition of research methodology, sample, and hypotheses.

\section{Research Methodology Defining the Sample and Research Methods}

Economic studies generally accept that business performance in one year is a good starting point for business success in the next business year (Cabrera-Suarez et al., 2018; Barros, Hernangomez \& Martin-Cruz, 2016; BarrosoMartinez, Sanguino-Galvn \& Palacios, 2016). On the basis of this, further research relies on the fact that business success in one year is a necessary but not sufficient condition for business success in the next business year. A sufficient condition for doing business for food retailers is also investment in maintaining and improving food safety standards. For this reason, this research needs to define a sample of companies subject to analysis, hypotheses, as well as select adequate research methods.

The research sample consists of companies registered on the territory of the Republic of Serbia, dealing with food retail as the main activity, and having 5 or more employees. On the basis on business success in 2016 from official database of the Serbian Business Registers Agency (www.apr.gov.rs, www.boniteti.rs) it is selected 169 such companies. They participate with $6,25 \%$ in the total food retail turnover on the territory of the Republic of Serbia. In this way, the representativeness of the sample has been achieved in terms of market share which exceeds $5 \%$ of the total market share, but also representativeness from the point of view of employment, as the analysed companies have 3691 employees, which is about $5 \%$ of the staff engaged in food retail sector in Serbia.

The null hypothesis in this research is - Ho: Investing in maintaining and improving food safety standards in the previous business year has no impact on business performance in the next business year; while the alternative hypothesis is - H1: Investing in maintaining and improving food safety standards in the previous business year has an impact on business performance in the next business year.

In order to identify business performance in the previous year in companies analysed in this study, income per employee in the previous year in 000 RSD, i.e. for 2016 is used as the variable. As a measure of business performance in the following year, revenue per employee in 000 RSD in current 2017 is used. This data is obtained from the official financial reports of the companies analyzed (Official database of the Serbian Business Registers Agency, 2018). As a measure of investment in maintenance and improvement of food safety standards in the previous year, investment in HACCP standard recertification in the previous year per employee in $000 \mathrm{RSD}$, i.e. for 2016, is used. This data is obtained on the basis of the company survey, and is controlled using data on investment in intangible assets in the 2016 official balance sheet. In this study, control variables contributing to the business performance in the current year are cash balance in current 2017, current liquidity ratio in 2017, and short-term asset turnover ratio in 2017. This is obtained on the basis of calculations in official financial statements of the companies analysed. These control variables are definitely indicators that positively influence business performance of companies mainly engaged in trade and are generally accepted in economic literature (Sanford, 2011; Kozielski, 2016; Singht \& Stout, 2018; Krupka, Ozretic-Dozen \& Previsic, 2017; Grubor, Milicevic \& Mijic, 2013).

The main objective of the paper is to analyses the impact of investment in HACCP standard recertification, cash balance, current liquidity ratio, short-term asset turnover, income per employee on the prediction of revenue per employee. Adaptive neuro-fuzzy inference system (ANFIS) is used to determine the parameter influence on the revenue per employee prediction. Variable selection process is used to select the most dominant factors that affect the revenue per employee prediction.

In this study, adaptive neuro-fuzzy inference system (ANFIS) (Jang, 1993; Erdirencelebi \& Yalpir, 2011; Tan et al., 2017; Jovic et al., 2019; Yadegaridehkordi et al., 2018a; Yadegaridehkordi et al., 2018b) is used to determine the most dominant factors for the revenue per employee prediction. There is one input and five outputs (Table 2). Original data can be found in an Appendix. 
Input and Outputs

\begin{tabular}{|l|l|l|l|l|l|}
\hline \multicolumn{1}{|c|}{ Input } & \multicolumn{1}{c|}{ Output 1 } & \multicolumn{1}{c|}{ Output 2 } & \multicolumn{1}{c|}{ Output 3 } & Output 4 & \multicolumn{1}{c|}{ Output 5 } \\
\hline $\begin{array}{l}\text { Revenue per } \\
\text { employee in the } \\
\text { current year in } \\
\text { 000 RSD (2017) }\end{array}$ & $\begin{array}{l}\text { Investment in HACCP } \\
\text { standard recertification in the } \\
\text { previous year per employee } \\
\text { in 000 RSD (2016) }\end{array}$ & $\begin{array}{l}\text { Cash balance in } \\
\text { 000 RSD in the } \\
\text { current year (2017) }\end{array}$ & $\begin{array}{l}\text { Current liquidity } \\
\text { ratio in the current } \\
\text { year (2017) }\end{array}$ & $\begin{array}{l}\text { Short-term asset } \\
\text { turnover ratio in the } \\
\text { current year (2017) }\end{array}$ & $\begin{array}{l}\text { Income per employee } \\
\text { in the previous year in } \\
\text { 000 RSD (2016) }\end{array}$ \\
\hline
\end{tabular}

Source: Authors

ANFIS network has 5 layers (Jang, 1993). The main core of the ANFIS network is fuzzy inference system. Layer 1 receives inputs and converts them into the fuzzy value by membership functions. In this study, bell-shaped membership function is used, since the function has the highest capability for the regression of the nonlinear data.

Bell-shaped membership function is defined as follows:

$$
\mu(x)=\operatorname{bell}\left(x ; a_{i}, b_{i}, c_{i}\right)=\frac{1}{1+\left[\left(\frac{x-c_{i}}{a_{i}}\right)^{2}\right]^{b_{i}}}
$$
input.

where $\left\{a_{i}, b_{i}, c_{i}, d_{i}\right\}$ is the parameter set and ${ }^{x}$ is

The second layer multiplies the fuzzy signals from the first layer and provides the firing strength of as rule. The third layer is the rule layers where all signals from the second layer are normalized. The fourth layer provides the inference of rules and all signals are converted into crisp values. The final layer summarizes all signals and provides the output crisp value.

\section{Results and Discussion}

ANFIS network is training for each output to determine the output influence on the given input. The influence of the outputs on the input can be determined according to the RMSE values. The output with the smallest training RMSE has the highest influence or relevance on the input. According the results below, the output 5 has the smallest training RMSE, therefore, the highest relevance for the input.

output 1 --> training=7704.1826, checking $=5474.5788$ output 2 --> training $=8521.3339$, checking $=4218.7624$ output 3 --> training $=8104.4365$, checking $=4498.9401$ output 4 --> training $=8057.2889$, checking $=6044.2556$ output 5 --> training $=7415.5606$, checking $=9765.1636$

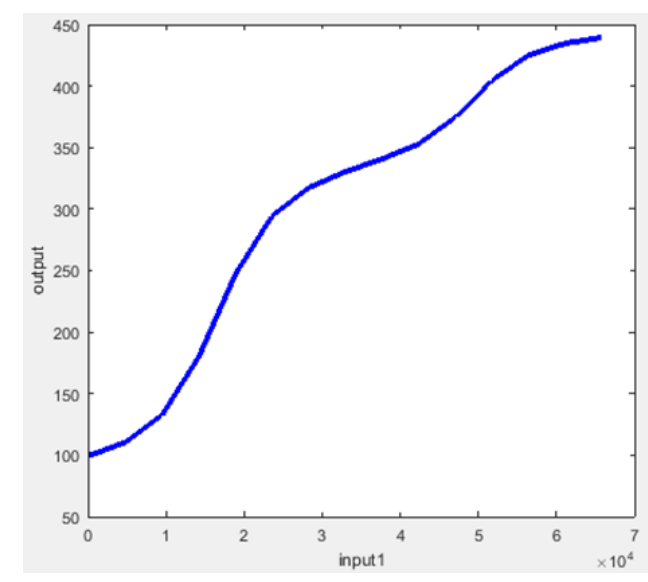

Figure 1. Output-1, Investment in HACCP Recertification

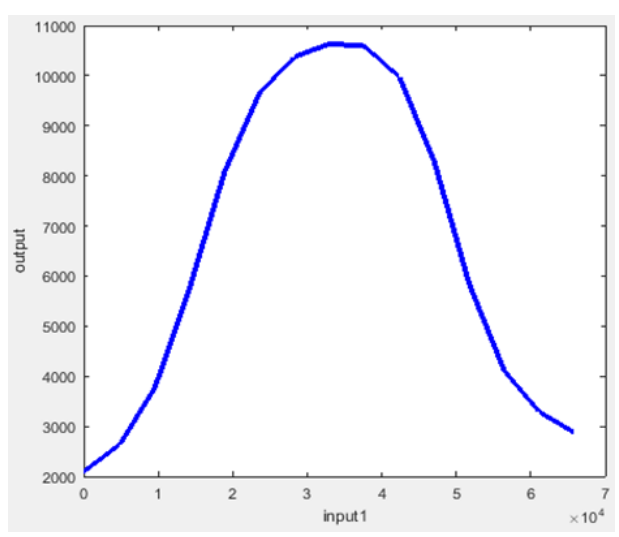

Figure 2. Output-2, Cash Balance

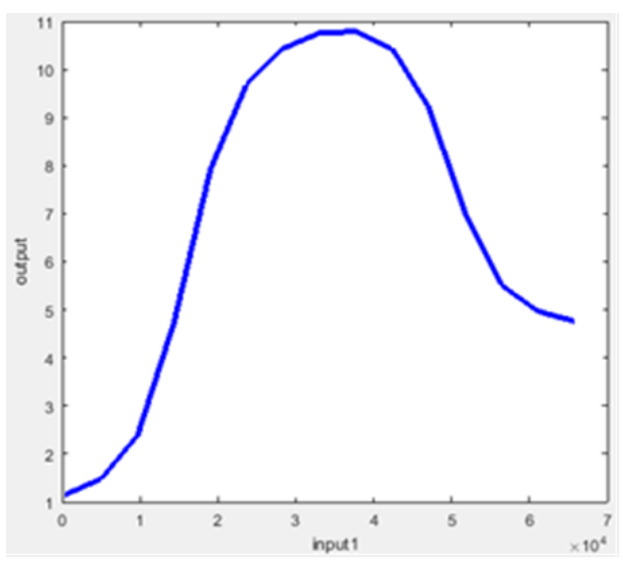

Figure 3. Output-3, Current Liquidity Ratio

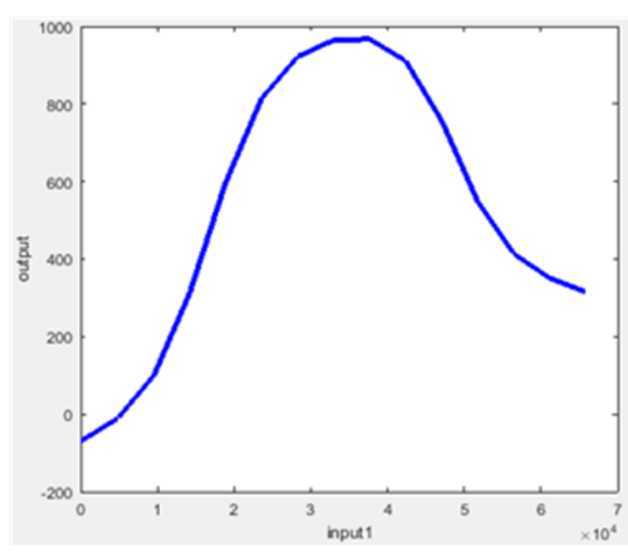

Figure 4. Output-4, Short-Term Asset Turnover Ratio 


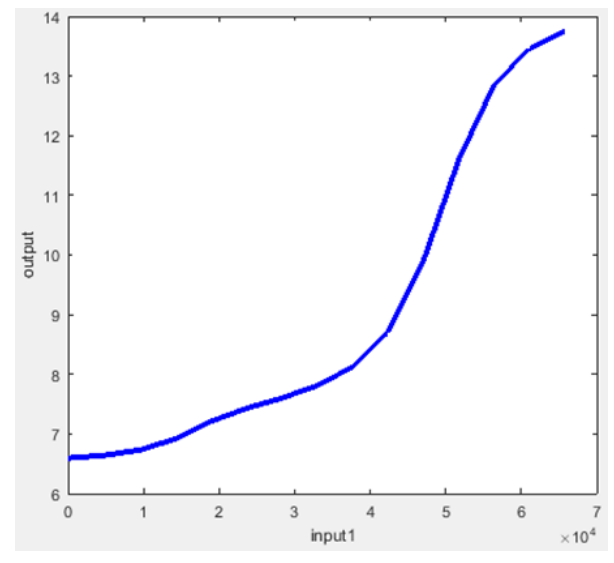

Figure 5. Output-5, Income per Employ

These figures (from 1 to 5) represent the obtained relationships between the used outputs and input. In other words, these figures represent nonlinear relationship between outputs and input. The adequate cash balance, current liquidity ratio, and short-term asset turnover in the current year are outputs. In order to have proper explanation of a result it is important to emphasise nonlinear relationship between outputs and input. In linear models, outputs are considered dependent and input are considered independent variables. In nonlinear models it is possible to utilise one of outputs as input and vice versa. This ability of nonlinear methodology to utilise sets of date regardless of linear interpretation presents a huge opportunity to discover new causal relationships. It should be emphasized that $50 \%$ of data are used for training and remaining $50 \%$ data are used for testing or control of the ANFIS models. The results clearly indicated which output has the most relevance to the input according to the training errors. In our research the output 5 has the smallest training error. Therefore, output 5 (Income per employee) has most relevance for input (Revenue per employee in the current year). ANFIS network training for each output (Investment in HACCP standard recertification, Cash balance, Current liquidity ratio, Shortterm asset liquidity ratio, Income per employee) is presented in diagrams from Figure 1 to 5.

Methodology of ANFIS network application is primarily based on data since there is causal relationship between data and network training. In other words, if the available data have some gaps the obtained results could be nonlinear regardless of the real interpretation of the results which should be linear. This means that beside creating nonlinear relationship, ANFIS is used to predict data. If there is substantial set of date ANFIS is used for nonlinear prediction.

Presented results in Figure 5 show that output Income per employee has smallest training RMSE, so has the highest influence or relevance on the input meaning Revenue per employee. Diagram in Figure 1 shows that Investment in HACCP standard recertification has second highest influence or relevance on Revenue per employee. Figure 2 represents Cash balance, Figure 3 represents Current liquidity ratio and Figure 4 represents Short-term asset liquidity ratio on Revenue per employee. It follows that:
- output 1 --> Investment in HACCP standard recertification has a $2^{\text {nd }}$ class influence on Revenue per employee,

- $\quad$ output 2 --> Cash balance has a fifth class influence on Revenue per employee,

- output 3 --> Current liquidity ratio has a fourth class influence on Revenue per employee,

- $\quad$ output 4 --> Current liquidity ratio has a third class influence on Revenue per employee,

- $\quad$ output 5 --> Income per employee has a first class influence on Revenue per employee.

The obtained research results show that business performance in the previous year (income per employee in $000 \mathrm{RSD}$ in 2016) is the crucial factor for business performance (income per employee in 000 RSD) in 2017. This is a well-known fact and in accordance with the accelerator principle, generally accepted in Keynesian economic theory. That is, growing revenues in one year, according to the principle of acceleration, create a precondition for higher investment and higher revenues in the next year. The importance of the results of this study is reflected in the fact that the next most important factor determining income per employee in 2017 for companies engaged in food retail is the investment in recertification of HACCP standards per employee in 000 RSD in 2016. This proves the alternative hypothesis $\mathrm{H} 1$, that investing in maintaining and improving food safety standards in the previous business year has an impact on business performance in the next business year. The research also showed that an adequate cash balance, current liquidity ratio and short-term asset turnover ratio in the current year are determinants of business performance in the same business year for companies engaged in food retail in the Republic of Serbia.

\section{Conclusion}

Trade, in particular retail, is an important economic segment in a number of countries, bearing in mind its share in GDP, total employment, and gross value added. Retail involves different product sales activities to end consumers. The available statistical data indicates that food retail has a significant share in total retail, viewed in terms of sales volume. These trends are dominant all around the world, in the Republic of Serbia as well, since food retail accounts for more than $30 \%$ of the total retail. Food retail, as well as total retail, is in direct contact with consumers. It gets all information about satisfaction or dissatisfaction with products and services directly from consumers, but also has the responsibility to offer them healthy and safe products. Food safety and security are one of the key consumer requirements which retailers should respond to, in addition to all other entities involved in the entire food supply chain. The issue of food safety and security has been institutionalized through the introduction of food quality control standards, such as HACCP. At the same time, a new research area opens, where HACCP is investigated and analysed from a variety of standpoints. In addition to examining the impact of the HACCP standard on consumer behaviour in purchasing decisions, there is a small number of papers and studies on the impact of food quality standards on retail performance. This has created the motive for 
research presented in this paper. The research included a sample of 169 retail companies in the Republic of Serbia. These are companies with 5 or more employees. Representativeness of the sample has been ensured, both in terms of market share, and the share in the total number of retail employees. The available financial data used in this paper was taken from the official website of the Serbian Business Registers Agency, as well as by interviewing the sample companies. The ANFIS method was used to test the impact of various parameters, including investment in HACCP standard recertification, on revenue per employee as an important retail business performance indicator. ANFIS had been selected since it is suitable for nonlinear data regression. Conventional methods have drawbacks in comparison to the ANFIS since ANFIS uses fuzzification in order to normalize the data samples. In other words, if some data samples are missing or if some data samples have errors the ANFIS could overcome it by if-then rules. The obtained research results show that business performance in the previous year (expressed through the parameter income per employee) is a necessary condition for business performance (revenue per employee) in the current year. A sufficient condition for business performance for food retailers is investment in HACCP standard recertification per employee (in the previous year). In this way, a hypothesis on the positive impact of investment in maintaining and improving food safety standards on the performance of food retailers has been proven. Additionally, the research results cover the research gap identified in scientific literature. It refers, first of all, to the lack of studies on the measurement of the impact of food control introduction, primarily HACCP, on the business performance of retailers. Also, the research findings in this paper can serve retail managers as a guide when making decisions about introducing HACCP certificates into business.

Presented research results, however, have some research limitations. First of all, the obtained research results only refer to the market of the Republic of Serbia. Furthermore, the limitations relate to the research sample and the period of observation. More detailed research would involve a greater number of observations, i.e. a larger number of food retailers, a longer period of analysis, and a greater number of countries involved in the analysis in order to make certain comparisons.

\section{References}

Al-Busaidi, M. A., \& Jukes, D. J. (2015). Assessment of the food control systems in the Sultanate of Oman. Food Control, 51, 55-69. http://dx.doi.org/10.1016/ j.foodcont.2014.10.039.

Al-Kandari, D., \& Jukes, D. J. (2012). The food control system in Saudi Arabia e centralizing food control activities. Food Control, 28(1), 33-46. http://dx.doi.org/ 10.1016/j.foodcont.2012.03.030.

Alomirah, H. F., Al-Zenki, S. F., Sawaya, W. N., Jabsheh, F., Husain, A. J., Al-Mazeedi, H. M., Al-Kandari, D., \& Jukes, D. (2010). Assessment of the food control system in the State of Kuwait. Food Control, 21(4), 496-504. http://dx.doi.org/10.1016/ j.foodcont.2009.07.015.

Barros, I., Hernangomez, J., \& Martin-Cruz, N. (2016). A theoretical model of strategic management of family firms: A dynamic capabilities approach. Journal of Family Business Strategy, 7(3), 149-159. https://doi.org/10.1016/ j.jfbs.2016.06.002.

Barroso-Martinez, A., Sanguino-Galvan, R., \& Palacios, T. M. (2016). An empirical study about knowledge transfer, entrepreneurial orientation and performance in family firms. European Journal of International Management, 10(5), 534-557. https://doi.org/10.1504/EJIM.2016.078790.

Berman, B. R., Evans, J. R., \& Chatterji, P. (2018). Retailing Management: A Strategic Approach. New York: Pearson Education.

Brynjolfsson, E., Hu, Y. J., \& Rahman, M. S. (2013). Competing in the age of omnichannel retailing. MIT Sloan Management Review, 54(4), 23-29.

Cabrera-Suarez, M.K., Garcia-Almeida, D. J., \& De Saa-Perez, P. (2018). A Dynamic Network Model of the Successor's Knowledge Construction From the Resource- and KnowledgeBased View of the Family Firm. Family Business Review, 31(2), 178-197. https://doi.org/10.1177/0894486518776867.

Caswell, J. A. (1998). Valuing the benefits and costs of improved food safety and nutrition. The Australian Journal of Agricultural and Resource Economics, 42(4), 409-424. https://doi.org/10.1111/1467-8489.00060

Diamond, J., \& Litt, S. (2010). Retailing in the twenty-first century. New York: Fairchild Books.

Dunne, P. M., Lusch, R. F., \& Carver, J. R. (2014). Retailing. Canada: South-Western Cengage Learning.

Erdirencelebi, D., \& Yalpir, S. (2011). Adaptive network fuzzy inference system modeling for the input selection and prediction of anaerobic digestion effluent quality. Applied Mathematical Modelling, 35(8), 3821-3832. https://doi.org/10.1016/j.apm.2011.02.015

European Commission. (2013). Consumers-Putting the consumers first. [online] European Commission. Available at: https://publications.europa.eu/en/publication-detail/-/publication/25292734-514e-49da-8fcd-8628951b12d2. 
Svetlana Sokolov Mladenovic, Sreten Cuzovic, Igor Mladenovic, Dragan Stojkovic. The Importance of Food Control ...

European Commission. (2014). Food safety- From farm to fork: safe and healthy food for everyone. [online] European Commission. Available at: https://europa.eu/european-union/topics/food-safety_en.

European Food Safety Authority. (2018). How we work. [online] European Food Safety Authority. Available at: http://www.efsa.europa.eu/en/about/howwework.

Eurostat. (2018). Retail trade volume index overview. [online] Eurostat. Available at: http://ec.europa.eu/eurostat/statisticsexplained/index.php/Retail_trade_volume_index_overview\#Retail_trade_developments.

Finnengan, C., Runyan, R. C., Gonzalez-Padron, T., \& Hyun, J. (2016). Diversity and Rigor Trends in Retailing Research: Assessment and Guidelines. International Journal of Management Reviews, 18, pp. 51-68. https://doi.org/10. 1111/ijmr.12059.

Garcia-Garcia, G., Stone, J., \& Rahimifard, S. (2019). Opportunities for waste valorisation in the food industry in case study with four UK food manufacturers. Journal of Cleaner Production, 211, 1339-1356. https://doi.org/10. 1016/j.jclepro. 2018.11.269.

Global Power of Retailing, 2015-2019. [online] Deloitte Touche. Available at: http://www2.deloitte.com/be/en/pages/ consumer-business/articles/global-powers-of-retailing.html.

Grewal, D., Ailawadi, K. L., Gauri, D., Hall, K., Kopalle, P., \& Robertson, J. R. (2011). Innovations in retail pricing and promotions. Journal of Retailing, 87(1), 43-52. https://doi.org/10.1016/j.jretai.2011.04.008.

Grewal, D., Motyka, S., \& Levy, M. (2018). The Evolution and Future of Retailing and Retailing Education. Journal of Marketing Education, 40, 85-93. https://doi.org/10.1177/0273475318755838.

Grubor, A., Milicevic, N., \& Mijic, K. (2013). Empirical Analysis of Inventory Turnover Ratio in FMCG Retail Sector Evidence from the Republic of Serbia. Inzinerine Ekonomika-Engineering Economics, 24(5), 401-407. https://doi.org/10.5755/j01.ee.24.5.3546.

Grunert, K. G. (2005). Food quality and safety: consumer perception and demand. European Review of Agricultural Economics, 32(3), 369-391. https://doi.org/10.1093/eurrag/jbi011.

Hagberg, J., Sundstrom, M., \& Egels-Zanden, N. (2016). The digitalization of retailing: an exploratory framework. International Journal of Retail \& Distribution Management, 44(7), 694-712. DOI: 10.1108/IJRDM-09-2015-0140.

He, X., Deng, H., \& Hwang, H. (2019). The current application of nanotechnology in food and agriculture. Journal of food and drug analysis, 27, 1-21. https://doi.org/10.1016/j.jfda.2018.12.002.

Heikkila, J., Heinola, K., Laikko-Roto, T., \& Nevas, M. (2016). Evaluating the determinants of public and private costs of local food control. Food Control, 70, 145-151. https://doi.org/10.1016/j.foodcont.2016.04.017.

Henson, S., \& Northen, J. (2000). Consumer assessment of the safety of beef at point of purchase: a pan-European study. Journal of Agricultural Economics, 51(1), 90-105. https://doi.org/10.1111/j.1477-9552.2000.tb01211.x.

Herath, D., \& Henson, S. (2006). Does Canada need mandatory HACCP? Evidence from the Ontario food processing sector. Canadian Journal of Agricultural Economics/ Revue Canadienne d'Agroeconomie, 54(4), 443-459. https://doi.org/10.1111/j.1744-7976.2006.00060.x.

Hristov, L., \& Reynolds, J. (2015). Perceptions and practices of innovation in retailing: Challenges of definition and measurement. International Journal of Retail \& Distribution Management, 43(2), 126-147. https://doi.org/10.1108/ IJRDM-09-2012-0079.

Jang, J.-S.R. (1993). ANFIS: Adaptive-Network-based Fuzzy Inference Systems. IEEE Transactions On Systems, Man, and Cybernetics, 23(3), 665-685. https://doi.org/10.1109/21.256541

Jovic, S., Smigic Miladinovic, J., Micic, R., Markovic, S., \& Rakic, G. (2019). Analysing of exchange rate and gross domestic product (GDP) by adaptive neuro fuzzy inference system (ANFIS). Physica A: Statistical Mechanics and its Applications, 513, 333-338. https://doi.org/10.1016/j.physa.2018.09.009.

Kettunen, K., Lunden, J., Laikko-Roto, T., \& and Nevas, M. (2017). Towards more consistent and effective food control: learning from the views of food business operators. International Journal of Environmental Health Research, 27(3), 215-229. https://doi.org/10.1080/09603123.2017.1332351.

Kozielski, R. (2016). Determinants of Business Success - Theoretical Model and Empirical Verification. Folia Oeconomica Stetinensia, 16(1), 274-285. https://doi.org/10.1515/foli-2016-0018.

Krupka, Z., Ozretic-Dosen, D., \& Previsic, J. (2017). Antecedents of Brand Management Adaptation/Standardization and Its Influence on Firms' Performance. Inzinerine Ekonomika-Engineering Economics, 28(3), 334-346. http://dx.doi.org/10.5755/j01.ee.28.3.16884.

Kunc, J., \& Krizan, F. (2018). Changing European retail landscapes: New trends and challenges. Moravian Geographical Reports, 26(3), 150-159. https://doi.org/10.2478/mgr-2018-0012.

Levy, M., Weitz, B.A., \& Grewal, D. (2014). Retailing Management. New York: McGraw- Hill Education. 
Liu, R., Gao, Z., Nayga, R., Snell, H., \& Ma, H. (2019). Consumers' valuation for food traceability in China: Does trust matter? Food Policy, In press, available online 18 September 2019 https://doi.org/10.1016/j.foodpol.2019.101768.

Lovreta, S., \& Petkovic, G. (2018). Trgovinski menadzment. Beograd: Centar za izdavačku delatnost Ekonomskog fakulteta u Beogradu.

Meziane, Z. (2007). Future innovations in food and drinks to 2012-Trend convergence and emerging growth opportunities. London: Business Insights Ltd.

Official database of the Serbian Business Registers Agency (2018). Available at: www.apr.gov.rs; www.boniteti.

Porin, F., \& Mainsant, P. (1999). Quelles strategies pour les concurrents de la filiere bovine dans le contexte de l'apres ESB? Cahiers d'economie et Sociologie Rurales, 50, 78-103.

Sanford, C. (2011). The Responsible Business: Reimagining Sustainability and Success. San Francisco: Jossey-Bass.

Sarter, S., Sarter, G., \& Gilabert, P. (2010). Swot analysis of HACCP implementation in Madagascar. Food Control, 21(3), 253-259. https://doi.org/10.1016/j.foodcont.2009.05.015.

Scarpato, S., Rotondo, G., Simeone, M., Gomez, A., \& Gutierrez, P. (2017). How can food companies attract the consumer concerned about food safety? A logit model analysis in Spain. British Food Journal, 119(8), 1705-1717. https://doi.org/10.1108/BFJ-12-2016-0616.

Scott, B. S., Wilcock, A. E., \& Kanetkar, V. (2009). A survey of structured continuous improvement programs in the Canadian food sector. Food Control, 20(3), 209-217. https://doi.org/10.1016/j.foodcont.2008.04.008.

Singht, N. P., \& Stout, D. B. (2018). Knowledge flow, innovative capabilities and business success: performance of the relationship between small world networks to promote innovation. International Journal of InnovationManagement, 22(2), 1-35. https://doi.org/10.1142/S1363919618500147.

Souiden, N., Ladhari, R., \& Chiadmi, N. E. (2019). New trends in retailing and services. Journal of Retailing and Consumer Services, 50. 286-288. https://doi.org/10.1016/j.jretconser.2018.07.023

Statistical Yearbook of the Republic of Serbia, 2014-2018. [online] Statistical Office of the Republic of Serbia. Available at: www.stat.gov.rs/publikacije/publication/?p=10399.

Stefani, G., \& Henson, S. H. (2001). Assessing the value of labels about food safety attributes. In: Proceedings of the 71st EAAE Seminar: The food consumer in the early 21st century, Zaragoza, April 2001.

Tan, Y., Shuaia, C., Jiaoc, L., \& Shenb, L. (2017). An adaptive neuro-fuzzy inference system (ANFIS) approach for measuring country sustainability performance. Environmental Impact Assessment Review, 65, $29-40$. https://doi.org/10.1016/j.eiar.2017.04.004.

Verbeke, W., \& Viaene, J. (2001). Impact of the dioxin scare on consumer perception of fresh meat in Belgium. In: Proceedings of the 71st EAAE Seminar: The food consumer in the early 21st century, Zaragoza, April 2001.

Violaris, Y., Bridges, O., \& Bridges, J. (2008). Small businesses e big risks: current status and future direction of HACCP in Cyprus. Food Control, 19(5), 439-448. https://doi.org/10.1016/j.foodcont.2007.05.004.

Yadegaridehkordi, E., Nasir, M. H. N. B. M., Nilashi, M., \& Ibrahim, O. (2018a). Predicting determinants of hotel success and development using Structural Equation Modelling (SEM)-ANFIS method, Tourism Management, 66, 364-386. https://doi.org/10.1016/j.tourman.2017.11.012.

Yadegaridehkordi, E., Shuib, L., Hourmand, M., Nilashi, M., Ahani, A., \& Ibrahim, O. (2018b). Influence of big data adoption on manufacturing companies' performance: An integrated DEMATEL-ANFIS approach. Technological Forecasting and Social Change, 137, 199-210. https://doi.org/10.1016/j.techfore.2018.07.043.

Yapp, C., \& Fairman, R. (2006). Factors affecting food safety compliance within small and medium-sized enterprises: implications for regulatory and enforcement strategies. Food Control, 17(1), 42-51. https://doi.org/10.1016/ j.foodcont.2004.08.007.

The article has been reviewed.

Received in October 2019; accepted in December 2020.

This article is an Open Access article distributed under the terms and conditions of the Creative Commons Attribution 4.0 (CC BY 4.0) License (http://creativecommons.org/licenses/by/4.0/). 